\title{
低加速電子ビーム近接転写技術の開発*
}

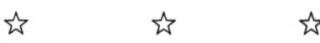

\section{島津信生 ${ }^{* *}$}

Development of Low Energy Electron Beam Proximity Projection Lithography / Nobuo SHIMAZU

Key words: lithography, electron-beam, X-ray, LSI, semiconductor, pattern, resist

1. はじめに

一産業発展と半導体技術の進歩——

半導体が発明されて 50 有余年, 情報・通信産業を含む 世界の産業は大きく発展してきた。この産業発展には, 3 年間で 4 倍の性能向上を継続してきた半導体, すなわち LSI の技術革新が大きく貢献している.このことは, 逆 に, もし半導体技術の進歩が停滞すれば, 今後の産業発展 は甚大な影響を受けることを意味している。

\section{2. リソグラフィー危機の本質}

一方, 最近のマイクロプロセッサに見られる熾烈な開発 競争がもたらした半導体パタンの微細化は極限にまで達し ており，次なる技術向上が極めて困難になっている．シリ コンウェーハに微細なパタンを形成するリソグラフィー技 術は, 半導体製造工程の $1 / 2$ から $2 / 3$ を占める重要な技術 である.このリソグラフィーが, 技術の壁に直面している 現状を「リソグラフィー危機」と一般に言うが, この危機 の本質はコストにある.

現在のリソグラフィーの主役である光ステッパは, 光源 にi 線を用いる装置（約 3.5 億円）から世代を経るにつれ て高価になっており, 次世代の F2 エキシマレーザ・ス テッパでは約 25 億円になると予想されている. そして, 計算機（大型計算機 $\rightarrow$ ワークテーションーパソコン）主 体の半導体の市場が, 家電製品や携帯電話などの個人用製 品へと移行しつつある中,「リソグラフィー危機」の克服 とは, 高性能（微細化）は当然として, 低価格で多種多様

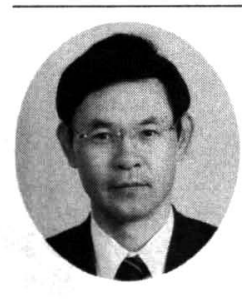

* 原稿受付 平成 13 年 6 月 29 日

** 正 会 員 (株) リープル（町田市本町田133713) 1977 年東京大学博士課程修了後, NTT 通信 研究所にて電子ピーム描画装置の開発に従事. 1999 年 4 月エンジェルラボ株式会社創設. 2000 年 6 月株式会社リープル代表取締役社長.
な微細パタン形成技術を実現すべきことにほかならない.

\section{LEEPL 発明の経緯}

光リソグラフィーは光回折によって微細パタン形成に限 界がある.このことは, 古くから問題とされ, X 線や電 子ビームを用いるリソグラフィー技術が長く研究・開発さ れてきた. しかし, 現在, 低コスト化を本質的な課題とす る「リソグラフィー危機」の克服には, 原理的な観点に立 ち戻って再検証をする必要がある。これを行い, 新たな着

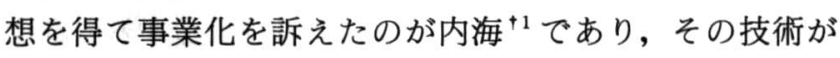
LEEPL $^{1)}$ (Low Energy Electron Beam Proximity Projection Lithography) である. 内海は電子ビームを用いた 次世代リソグラフィー技術には以下の条件が必要であると 考えた。

(1) ウェーハ直接描画ではなく, 転写方式であること.

(2) 電子ビームのパワーが小さいこと.

（3）空間電荷効果がないこと.

(4) 近接効果がないこと.

ここで，(1) については, 少量多品種生産にはウェーハ 直接描画が有効であるが, パタンデータ処理時間や長い描 画時間を考えると一定量以上の生産には転写方式がリソグ ラフィーの主流であるとの考えである.

\section{LEEPL の原理}

内海の考察は, シャドー・イメージングという簡単な原 理に至り, そこに低加速ビームの使用を加えた結果, 多く の利点が浮かび上がってきた.

図 1 に LEEPL の原理を示す. 穴あき（ステンシル） マ スクをウェーハに近接させる構成は, 等倍 $\mathrm{X}$ 線ステッパ と同一であるが，X 線の代わりに電子ビームでマスク上 を走査する点が異なる。この方式は, 20 年前に IBM が研 究2)を行っていた. しかし, $10 \mathrm{kV}$ の高加速電子ビームを 用いたためマスクが厚くなり, 高アスペクト比のステンシ 


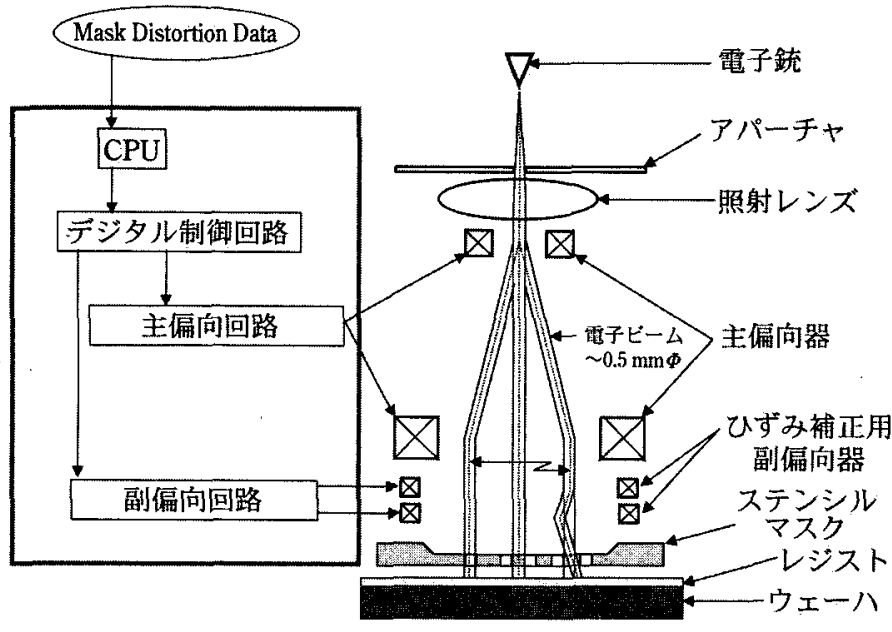

図 1 LEEPL の基本構成と動作原理

ルマスクパタンが必要となり，将来の微細化に対応できな いとして開発が中止された，一方，LEEPLでは加速電圧 $2 \mathrm{kV}$ の電子ビームを用いるため, マスク膜厚は $10 \mathrm{kV} の$ 場合の $1 / 25$ で斉み, 高アスペクト比の問題は大幅に軽減 する．すなわち，等倍マスクを用いる転写方式（上記の条 件（1）にに将来性を見出すことができた。

さらに，低加速電圧の電子ビームを用いるため，これが マスクとウェーハに与える熱量（パワー）は大幅に低滅す る.

図 2 に, LEEPL と他の次世代リソグラフィー候補がマ スクとウェーハに与える熱量を比較したものを示す.

LEEPL が与える熱量は, 他の方式の数 100 から数千分の 1 にすぎず，条件（2）を満足する，これは，電子ビーム の加速電圧とレジスト感度が反比例の関係にあることと， 電子ビーム自体が低加速であることとの相乗効果による. ここで PREVAIL とは SCALPEL（後述）と類似の技術 で 4 倍ステンシルマスクを使用する. X-RAY とは等倍 $\mathrm{X}$ 線リソグラフィーを指し，LEEPLと共通な技術項目を持 つ. IPL はイオンビームを用いるりソグラフィー技術で

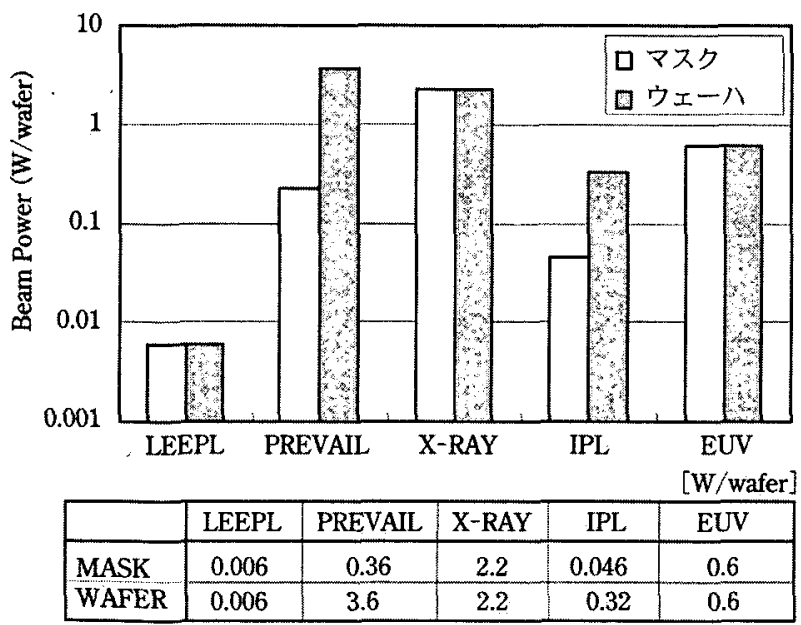

图 2 次世代リソグラフィー方式がマスクとウェー八に与える熱量 の比較
あり，4 倍ステンシルマスクを用いる.

条件（3）の空間電荷効果とは，電子が持つ電荷の相互 作用によって結像状態が損なわれることを言う.ビームの 電子数が多い（大電流）ほど，また，電子の集結筒所（ク ロスオーバー点) が多いほど,さらに，マスクから結像面 であるウェーハまでの距離が長いほど空間電荷効果は大と なる、高スループット（一般に大電流ビームを必要とす る）と微細パタン転写を両立させようとするとき，この空 間電荷効果が大きな障壁となる。しかし，LEEPL は小電 流ビームでも高スループットが実現でき，マスクーウェー 八間で電子ビームは平行であってクロスオーバーを持た ず，また，この間の距離は SCALPEL ${ }^{3)}$ 方式の数 $10 \mathrm{~cm}$ に比べて数 $10 \mu \mathrm{m}$ と短く, 条件（3）の空間電荷効果は無 視できる。

条件（4）の近接効果とは, 高加速電子ビームでは ウェーハ内部での散乱領域が大きく, 後方散乱電子のため 近接したパタンの分離ができなくなる現象を言う. $2 \mathrm{kV}$ の低加速電子ビームを用いる LEEPL では, 電子はレジス 卜層のみで散乱し, かつ, 散乱領域が小さいため近接効果 がほとんど無視できる。

\section{LEEPL の特長}

LEEPL は前述のすべての条件を満たす方式であるが, これに加えて装置構成が極めてシンプルであるため, 装置 製造コストが低隇できる。すなわち，LEEPLは，冒頭述 べたリソグラフィー装置価格の上昇傾向を阻止できる技術 である.これを，SCALPEL 方式との比較で見てみよう。 なお，スカルペルとは 4 倍マスクパタンを $100 \mathrm{kV}$ の高加 速電子ビームを用いて縮小転写する方式である.ほとんど の電子はマスクを通過するためマスクの発熱が抑制でき る、マスク通過時の電子散乱の有無によって像のコントラ ストを得る。

（1）4 倍マスクを用いる SCALPEL は，複数回の往復 動作で 1 チップのパタン転写をする.このため, マスク全 面をビーム走査するには, マスクの高加速・高速移動を必 要とする.すなわち，高速高精度な真空内マスクステージ を必要とし，振動抑制を図るために装置が大型化する。一 方, LEEPLの場合, 転写中にマスクは停止しているた め, 高性能な真空マスクステージは不要である。

(2) SCALPEL では，4倍マスクパタンをウェーハ上 に結像するため縮小投影電子光学系を必要とする. 大電流 で微細パタンを転写するために，この電子光学系には低収 差と空間電荷効果の抑制を考慮した設計が必要となる。 た, 電子光学系のレンズや偏向器を駆動する電源・ビーム 偏向回路系の規模が大となる。一方，LEEPL の電子光学 系は, SCALPELの照射光学系に相当する部分のみで凧 み，構成が簡単である。

(3) SCALPELの 4 倍マスクはSTRUTSで分割され ているため，転写に際してはこの部分を転写しないように して，分割されたパタンをつなぐ。これを，ウェ一ハス 
テージとマスクステージのそれぞれが移動する中で行うた め, 高度なビーム位置決め制御を必要とする。一方, LEEPL では分割されていないマスクを用いるため, この ようなビーム位置決め制御は不要である.

\section{LEEPL の課題}

構造の簡単な LEEPL 転写装置の開発には深刻な課題は ないと考えられる。むしろ, 等倍ステンシルマスクが LEEPL 実用化の最大の課題である。また，レジスト内へ の侵入深さの浅い低加速ピームを使用する LEEPL では, 薄い表層レジストを用いる多層レジストプロセスの開発が 課題となる. 等倍マスクについては, 最近の等倍 X 線マ スク製造技術の向上には目覚ましいものがある. 等倍 X 線マスクと等倍ステンシルマスクの共通点は多く, これま で培われてきた等倍X線マスク製造技術の活用が LEEPL 確立には不可欠である.

レジストの薄膜化は, 時代の趨勢である. 実際, パタン の微細化はレジストパタンのアスペクト比を高くし, レジ ストパタンを倒壊させることもある。 また, 次世代光ス テッパ（F2ステッパなど）やX 線縮小投影リソグラ フィー (EUV とも言う) で用いる光や X 線の波長はいず れも短く, レジスト内侵入深さが浅い. このため, LEEPL に限らず, 薄膜レジストの使用は他の次世代リソ グラフィー候補にとっても不可避である.

LEEPL 開発にとって最も重大かつ深刻な側面は, 開発 のために残されている時間が短いことにある. LEEPL 以 外の次世代リソグラフィー候補には 25 年以上前から研究 が進められてきたものもある. 一方, 前述の半導体微細化 の急進展によって, 研究が開始されたばかりの LEEPLに 対して, 実用化までの時間は, 2 年から 3 年程度しかない.

\section{LEEPL 開発の開始}

LEEPL の優れた特長と社会的意義の重大さを認識した (株) 東京精密と著者は, 発明者の内海と共に 2000 年 6 月 に会社（(株)リープル）を設立して LEEPL の実用化を目 指すこととした. 会社設立に先立って，内海 と著者は, 等倍ステンシルマスクの実現可能 性を吉原 ${ }^{+2}$ に尋ねた。等倍 X 線マスク開発 に豊富な経験 ${ }^{4)}$ を持つ吉原は, それが可能で あると即答し，このことは後に実証された。

LEEPL 実用化で最初に行うべきことはパ タン転写実験を通して,コンセプトを実証す ることである.このため, (株)リープルは, コンセプト実証用の実験機（ $\alpha$ 機）の製造, 等倍ステンシルマスクの開発, そして LEEPL 用多層レジスト開発に着手した。こ れらすべてを 4 カ月以内で完了して 2000 年 10 月から転写実験を通して LEEPL コンセ プトの実証を行った。

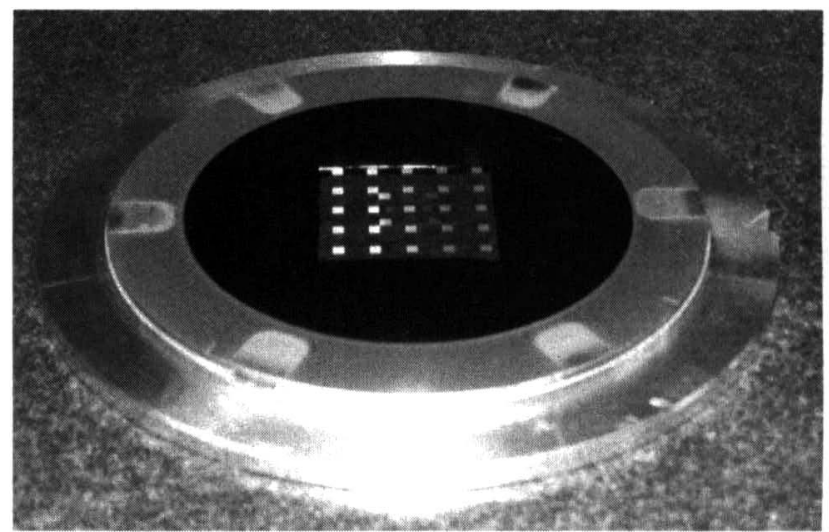

図 3 ホルダーに装着された LEEPL ステンシルマスクの外観

\section{$7.1 \alpha$ 機の製造}

$\alpha$ 機の製造では, 電子光学系を(株)アプコに, マスク やウェーハステージを含む機構系を京セラ(株)に依頼し た. 常識外れの短納期と急な注文にもかかわらず, 技術担 当者は時間単位で製造計画を立て，予定通りに製造を完了 した. $\alpha$ 機は, $\mathrm{ZrW}$ 熱電界放射銃（TFE 銃）を搭載し, $25 \mathrm{~mm}$ 角領域を電子ビームで走査して一括転写する。 そ して, 6 インチまたは 8 インチウェー八全面の転写が可能 である。

\subsection{LEEPL マスクの開発}

LEEPL マスクについてはNTT アドバンステクノロジ (株)に開発を依頼した。同社は, 多結晶ダイヤモンド薄膜 を使用したステンシルマスクを短期間で開発した. 図 3 に ホルダーに装着されたマスクの外観を示す。また，図 4 に, 同マスクに形成されている $70 \mathrm{~nm}$ のステンシルマス クパタンを示す.このパタンの側壁についても, グレイン の痕跡もなく，垂直で良好であることを確認した。

\section{3 レジストプロセス}

コンセプト実証に用いるレジストプロセスについても NTT アドバンステクノロジ(株)に開発を依頼した.従来,
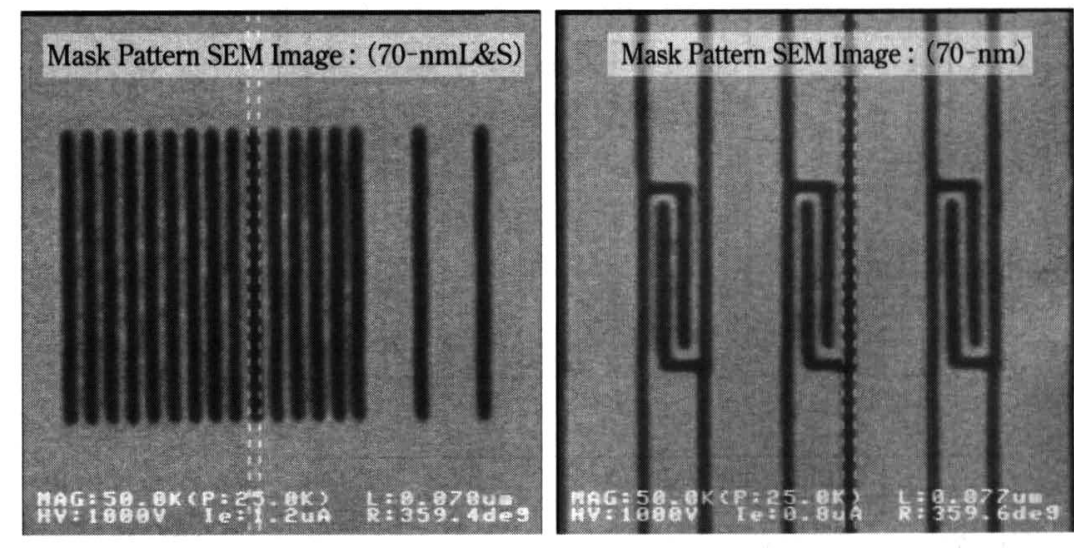

図 4 LEEPL マスクに形成された $70 \mathrm{~nm}$ のステンシルマスクパタン 


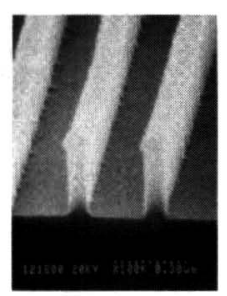

$0.17 \mu \mathrm{m} L \& S$

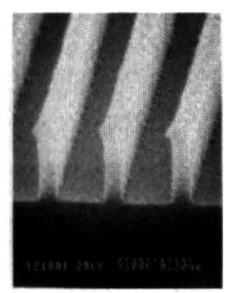

$0.15 \mu \mathrm{m} \mathrm{L} \& \mathrm{~S}$

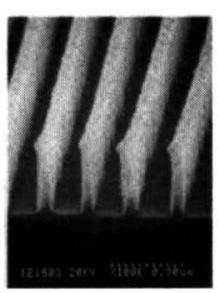

$0.10 \mu \mathrm{m} \mathrm{L} \& \mathrm{~S}$
Cross sectional SEM view after $\mathrm{O}_{2} \mathrm{RIE}$

図 5 下層レジストエッチング後のレジストパタン （表層SPP レジスト）

多層レジストプロセスでは, 表層レジストを現像した後, シリル化を行って，シリル化したレジストパタンをマスク にして下層レジストのエッチングを行っていた. NTTア ドバンステクノロジ(株)では, 同社の開発したシリコン含 有レジスト (Silicon-based Positive Photoresist. 以下 SSPレジストと称す.）を用いて，シリル化行程を含まな い実用性の高いプロセスを開発した. SPPレジストは, 電子ビームを転写後, 紫外線を全面に照射すると, 電子 ビーム照射領域のみがネガ形に反転し，かつ，エッチング 耐性を持つようになる. 通常の現像後, エッチング耐性を 持ったレジストパタンをマスクにして下層レジストのエッ チングを行えばよい. 図 5 に下層レジストエッチング後の レジストパタンを示す.

図 6 は近接効果の評価用のレジストパタンを示す. 中央 の孤立ラインに大パタンが近接している領域でも良好なパ タンが形成できていて, 近接効果のないことがわかる.

\section{8. 今後の開発計画}

$\alpha$ 機のこれまでの実証実験の結果, LEEPL の実現性が

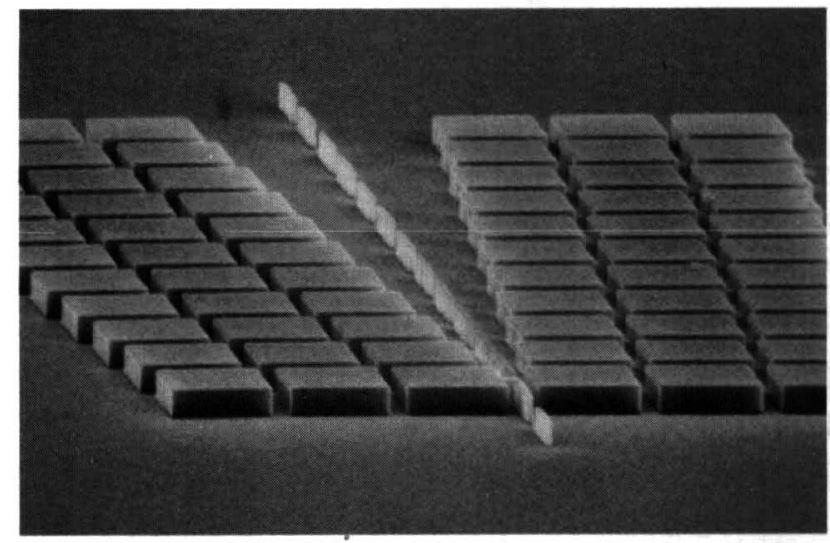

図 6 近接効果の評価用のレジストパタン

高いと判断した(株)リープルは $\beta$ 機の開発に着手した. $\beta$ 機は量産機に近い装置として，2001 年末までに製造する 予定である. $\beta$ 機の仕様を表 1 に示す. $\beta$ 機ではビーム電 流 $20 \mu \mathrm{A}$ を得ようとしている.これは, $100 \mathrm{kV}$ の加速電 圧を用いる SCALPEL と比べてレジスト感度が 50 倍向上 するため, SCALPEL で $1000 \mu \mathrm{A}$ の大電流を使用するこ とに相当する. なお, SCALPEL では $30 \mu \mathrm{A}$ がビーム電 流值の目標仕様である。このように実効的に極めて高い電 流值が得られる LEEPL では, スループット向上には, 実 転写時間の短縮よりも，ステージ移動やマーク検出などの オーバヘッド時間短縮が大切となる。

量産機は 2003 年 4 月から供給を開始する予定である. 図 7 に量産機のスループット予測を示す. $9 \mu \mathrm{A}$ でチップ (薄膜部ウインドー) サイズ $25 \mathrm{~mm}$ 角の場合, $300 \mathrm{~mm}$ ウェーハで時間当たり 40 枚が, そして，2枚 1 組の相補 マスクを用いた場合では 30 枚のスループットの実現を目 指す.

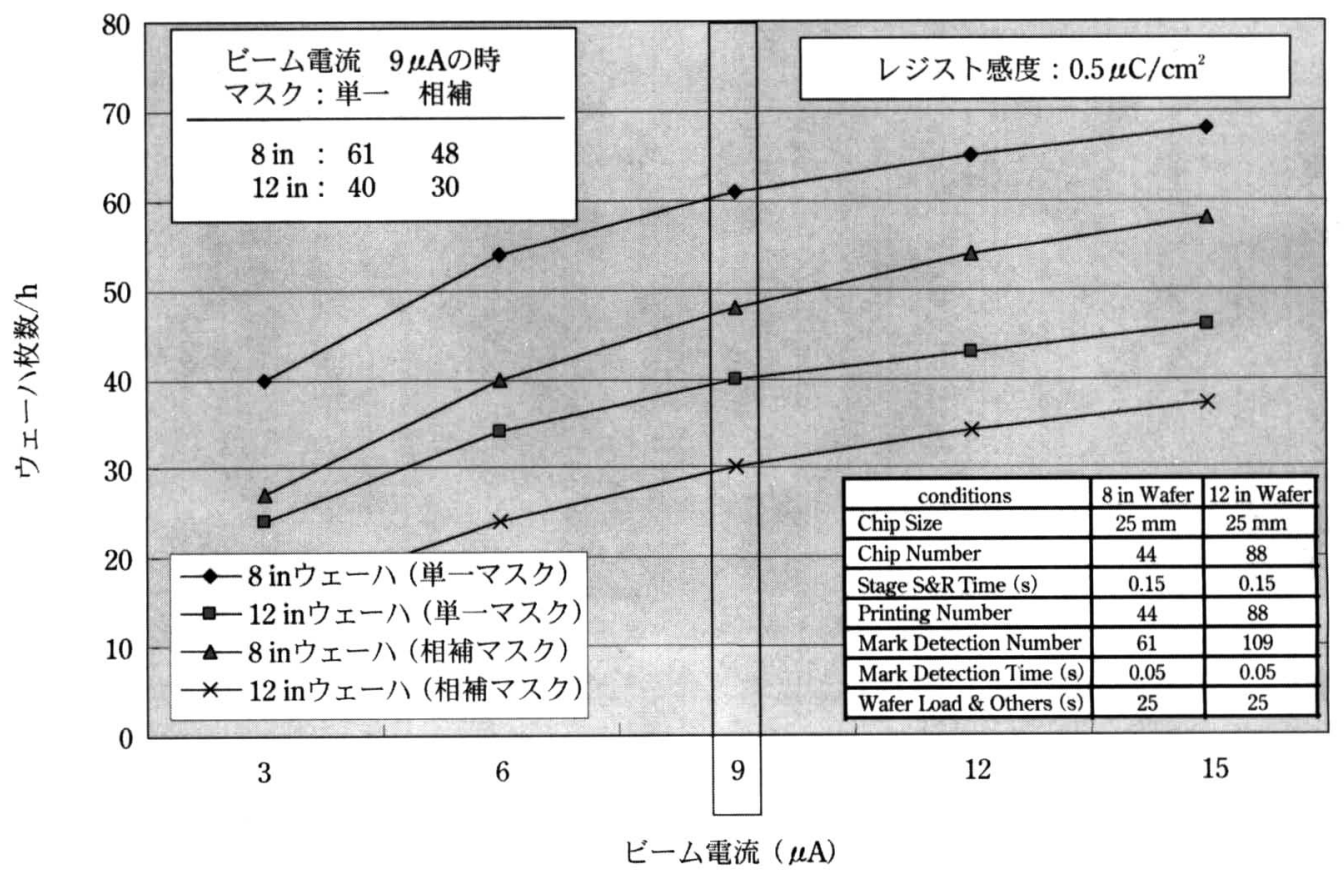

园 7 LEEPL 量産機のスループット 


\section{LEEPL コンソーシアムの発足}

次世代リソグラフィー開発の社会的意義は重大である。 また，リソグラフィーは複数の技術分野から成り立ってい るため，関連する技術分野が連携して実用化に向かうこと が不可欠である.このため, 関係各位のご努力・ご協力を 得て 2001 年 6 月 14 日に LEEPL コンソーシアムが発足し た。発足にあたっては，半導体メーカ 3 社，マスクメーカ 4 社, レジストメーカ 3 社, 装置メーカ 3 社の計 13 社が 参加しているが，コンソーシアムとしては，今後も関連 メ一カの参加を幅広く呼びかけていく予定である，今後は コンソーシアム・メンバーが中心となって, 前述の $\alpha$ 機 と $\beta$ 機を用いた技術評価を進めていくことになる。

表 $1 \beta$ 機の開発コンセプトと仕様

・開発コンセプト

シンプルな構成

低コスト低価格

圆既存技術の組合わせで高性能化

短期間で開発

- Specification of main items

\begin{tabular}{|c|c|}
\hline \multicolumn{2}{|c|}{ 棈デザインルール：100-70 nm } \\
\hline 畕分解能 & $: 70-50 \mathrm{~nm}$ \\
\hline 回焦点深度 & : over $6 \mu \mathrm{m}$ \\
\hline 回合わせ精度 & $: 35 \mathrm{~nm} \sim 25 \mathrm{~nm}(\mid$ Mean $\mid+3 \sigma)$ \\
\hline 圆ビーム電流 & $: 3 \sim 20 \mu \mathrm{A}$ \\
\hline $\begin{array}{l}\text { 图 スループット } \\
\text { 量産機 }\end{array}$ & $\begin{array}{l}: \text { over } 20 / \mathrm{h} @ 300 \mathrm{~mm} \text { wafer } \\
: \text { over } 40 / \mathrm{h} @ 300 \mathrm{~mm} \text { wafer }\end{array}$ \\
\hline 四ビーム走査領域 & $: 40 \mathrm{~mm} \times 40 \mathrm{~mm}$ \\
\hline 㖥ウェー八径 & $: 200 / 300 \mathrm{~mm}$ wafer \\
\hline アスク寸法 & : 4 inch or inch \\
\hline
\end{tabular}

\section{0.終わりに}

LEEPL は異例の速度で開発が進められているが，これ は，等倍X線リソグラフィーや電子ビームリソグラ フィ一技術の成果をそのまま継承している結果にほかなら ない. 特に，わが国では，これらの技術開発に多大の努力 が注がれてきた。わが国が世界に問う LEEPLには，これ ら技術開発の成果活用という使命を持つ.

LEEPL を含め, すべての次世代リソグラフィーにとっ てマスクが最大の技術課題である，幸い，構造が簡単な LEEPL では，装置開発に要するリソースは他の次世代リ ソグラフィ一候補と比較して小さくて済む。このため, LEEPL 開発のリソースの大部分はマスク開発に回すこと ができる、マスクは半導体設計を通して人間の知的活動が 集約される所であり，ここにこそ最大の開発りソースを投 入していくべきであろう。このためにも，最短で効率のよ い LEEPL 転写装置の開発に努力したいと著者らは考えて いる.

\section{参考 文 献}

1) T. Utsumi : Low energy electron-beam proximity projection lithography-Discovery of a missing link, J.Vac. Sci. Technol. B 17 (6), 11/12 (1999) 2897.

2) H. Bohlen, et al. : High throughput Submicron Lithography with Electron Beam Proximity Printing, Solid State Tech., 9, (1984) 210.

3) L. R. Harriott, et al. : Space charge effects in projection charged particle lithography systems, J. Vac. Sci. Technol. B13 (6), 11/12，(1995) 2404

4）ダイヤモンド社, : テクノロジー・ストリーミング——技術頭 脳集団 NTT-AT の挑戦——(2000.2) 